\title{
Kitan szavak listája Ligeti Lajos MTA-ra hagyott jegyzeteiben - számnevek
}

A Magyar Tudomány 2019. decemberi számában részletes ismertetést olvashattunk Róna-Tas Andrástól a kitan írás és nyelv megfejtésének a történetéröl és jelenlegi állásáról. ${ }^{1}$ Ott is szóba került, hogy a magyar tudósok közül először Ligeti Lajos (1902-1987) kezdett el ezzel a témával foglalkozni. A néhai Ligeti Lajos akadémikus a XX. század egyik legbefolyásosabb tudósa volt az ázsiai történeti nyelvészet - és sok más egyéb - tudományterületen. Számos tudományos alterületet ő maga teremtett meg, míg mások fejlődéséhez alapjaiban járult hozzá. Életének utolsó éveiben fontosnak tartotta, hogy a felgyülemlett tudást olyan módon adja át utódainak, amely újabb kutatás alapját biztosíthatja. Ebben a szellemben az 1970-es évek végén teljes könyvtárát a Szegedi Tudományegyetemre (akkor József Attila Tudományegyetem) hagyományozta, ahol ez időszakban jött létre az Altajisztikai Tanszék. A nagyjából 11000 dokumentum jelentette a jelenleg Keleti Gyüjteménynek nevezett állomány alapjait az egyetem könyvtárában. Egy másik Keleti Gyüjtemény, a Magyar Tudományos Akadémia Könyvtáráé (MTAK) ${ }^{2}$ szintén gazdagodott Ligeti-hagyatékkal, noha más módon. Ligeti 1987-ben hunyt el, de élethosszig gyüjtött személyes tudományos jegyzeteit, vázlatait és kéziratait már 1978-ban a MTAK-ra bízta, amely végrendeletének megfelelően onnantól kezdődően 40 éven át egészen 2018-ig zárolva tartotta a gyüjteményt. 2018-ban az MTA Nyelv- és Irodalomtudományok Osztálya felállított egy szakértői bizottságot, amelynek feladata a több mint 70 doboznyi irat feldolgozása. ${ }^{3}$

A kéziratok jelentős része Ligeti később megjelent cikkeinek vázlatai, viszont sok közülük sosem jelent meg. Mivel a feldolgozás csak a közelmúltban kezdődött, ez a tanulmány egy, az utóbbiak közé tartozó dokumentumok egyikét vizsgálja.

Róna-Tas András 2019.

Ligeti az MTA alelnöke volt 1949 és 1970 között.

Ezek közül 58-at a MTAK Keleti Gyüjteménye, 12-t pedig a MTAK Kézirattára kezel. Ezúton fejezem ki köszönetemet e gyüjtemények munkatársainak, hogy lehetővé tették a dokumentumokhoz való hozzáférést. 
Ligeti a kelet-ázsiai filológia számos területén végzett úttörő kutatásokat, többek között, ha nem is a legfontosabb kutatási területei között, foglalkozott a kitan nyelv és a rejtélyes kitan írásrendszerek megfejtésével is. Akkoriban nem volt a maihoz hasonló fejlett kitankutatás, ezért tehát minden általa hozzáférhető adattal igyekezett dolgozni, ez elsősorban a $\mathrm{Liao}^{4}{ }^{4}$ (遼) dinasztia (i. sz. 907-1125) kínai nyelvü forrásait jelentette. Ligeti első, a témában megjelent munkája a „Kitaj nép és nyelv” címü cikke volt 1927-ben, és később is aktívan foglalkozott ezzel a kutatási témával. Az 1940-es évek végére és az 1950es évek elejére elegendő ismerettel rendelkezett a tárgyban ahhoz, hogy összegezze ezeket, eleinte laza, de jól elrendezett jegyzetcédulák formájában, amelyek tartalmáról később jegyzetekkel és bibliográfiai hivatkozásokkal ellátott tisztázatot készített. A következö - esetünkben pedig az utolsó - lépés az volt, hogy a létrejött szójegyzéket könyvtári cédulákon rendezte el, amelyeket egy későbbi publikáció alapjainak szánt, ez viszont ismeretlen okból végül sosem látott napvilágot. Jelen tanulmány célja, hogy Ligeti fenti iratcsoportja egy szegmensének vizsgálatával megvilágítsa, hogy milyen tudással rendelkezhetett egy vezető tudós a kitan nyelvről a múlt század közepén.

\section{Megjegyzések a jelölésekkel kapcsolatban}

Ligeti iratainak leírásakor szögletes zárójelben [ ] többletinformációkat, fordításokat, korrekciókat közlök; kisméretü nyilakkal « > közrezárva kihagyandó, hibás részeket; nagy nyilakkal $<>$ közrezárva pedig a kitan írásjegyekkel írt szavak átírásait jelölöm. Azért, hogy a saját javításaim megkülönböztethetők legyenek Ligetiéitől, az ő eredeti szögletes zárójeleit vonalas szögletes zárójelekre cseréltem 【』. A dőlttel szedett bibliográfiai leírások, magyarázatok akárcsak a táblázatok, a szerző sajátjai. A -•- jelölés az eredeti dokumentum számozott szakaszán belüli oldaltörést jelöl, a (...) pedig két adat közötti akár többoldalas kihagyást. A zárójeles ( ) számozás és a dőlttel szedett magyarázatok a szerzőéi, minden egyéb Ligetiéi.

A szövegben a magyarban meghonosodott kitan/kitaj alakok kivételével a kínai szavak pinjin átírását használom. 


\section{Ligeti forrásai}

Jóllehet ezek nincsenek külön bibliográfiában felsorolva, Ligeti a következő forrásokat jelölte meg jegyzeteiben:

KTKT K'i-tan kouo tche [Qidan guo zhi 契丹國志]

LC Leao che [Liao shi 遼史]

LT Leao tche [Liao zhi 遼志]

WTC Wou tai che [[Jiu] Wudai shi [舊]五代史]

HSM Histoire secrète des Mongols (Ligeti saját rekonstrukciója szerint)

TYYY Tche-yuan yi yu [Zhiyuan yiyu 至元譯語] (Ishida 1934 szerint)

TP (Stein cikke, T'oung Pao 35, 1939)

\section{A jegyzetek struktúrája ${ }^{6}$}

(I. mappa) Szójegyzék (Újra felhasznált A5 méretü lapok, gyakran korábbi kéziratok hátlapján.)

(1.) A megfejtett kitaj ${ }^{7}$ szavak jegyzéke 1954. június 29. (Ez a felsorolás egy elözetes változata a szójegyzéknek. 1 oldal, 50 számozott szó, az utolsó négy eltérö szinü tintával.)

(2.) Mots khitan ${ }^{8}$ [kitan szavak] (33 szó elözetes csoportositása nyelvtani és szemantikai kategóriák szerint. A római sorszámok mellett ceruzával irt

5 Ligeti jegyzeteiben ennél több forrást is felsorol anélkül, hogy külön listázta volna őket az (5.) részben, ezért az egyszerüség kedvéért a cikk témájához nem tartozó tételeket itt nem vettem figyelembe.

6 Ligeti kitan témájú jegyzetei a hagyatékának csak kis töredékét teszik ki. Az itt szereplő dokumentumok a következő MTAK-jelölésű dobozokból valók: 1/2(4); 5/4(4); 5/3(4), de az érthetőség kedvéért itt ezeket rendre (I.), (II.) és (III.) számú mappaként említem.

7 A kitaj/kitan népnévvel kapcsolatban ld. Róna-Tas 2016a. A magyar szakirodalomban hosszú ideig a népnév kitaj változata volt használatos, így a magyar szövegben Ligeti is ezt használta, francia szövegben pedig a khitan alakot. A legújabb magyar nyelvü tudományos munkák a kínai nyelvben ismert 契丹 alak átírását, a kitan formát részesítik előnyben.

8 Ligeti munkanyelve pályafutásainak korai éveitöl kezdve már Eötvös kollégistaként is a francia volt. Ezt a gyakorlatát tovább erősítette az 1920-as évekbeli párizsi tartózkodása, ahol Pelliot-tól, Masperótól és Bacot-tól tanult. Onnantól kezdve kevés kivétellel franciául írta a nemzetközi közönségnek szánt müveit, és ennek nyomát a jegy- 
arab számok szerepelnek, valószinüleg későbbi felülvizsgálat eredményeként, amely a (3.) rész alapjául szolgált. 1 oldal.)

I. Számnevek; II. Fémek; III. Állatok; IV. Idö; V. Had; VI. Noms de charge [Tisztségnevek]; VII. Térszín; VIII. Színek; IX. Használati tárgyak, eszközök [a IX számot áthúzta Ligeti]; X. Igék; XI. Melléknevek.

(3.) A kitaj szavak tárgyalási rendje (A szavak nyelvtani és szemantikai kategóriák szerinti csoportositásának tisztázata a (2.) rész ceruzával írt számozása alapján, további változtatásokkal. 2 oldal.)

I. Számnevek; II. Térszíni formák; III. Idő; IV. Állatok; V. Fémek, drágakövek; VI. Használati tárgyak; (2. oldal) VII. Had; VII[I]. Noms de charge [Tisztségnevek]; Színek; VIII [valójában IX.] Foglalkozások; IX [valójában X.] Egyéb fönevek; X [valójában XI.] Melléknevek; XI. [valójában XII.] Igék.

Ennek az oldalnak a hátuljára Ligeti az alábbiakat írta:

A megfejtett szavak száma 1952 VII. 18 ... 35 [Ez azt mutatja, hogy a (I.)(1.) pontban szereplö lista Ligeti munkájának egy késöbbi fázisát tartalmazza.]

(4.) [cím nélkül] (a szójegyzék tisztázata Nos. 1-46, 1 oldal)

(5.) Abréviation [Rövidítések] (nem teljes, 1. oldal)

(6.) Jours de fête K'i-tan [Kitan ünnepek] (16 kínai elnevezés, ahol lehetséges, kitan megfelelökkel, a Liao zhi holdnaptár szerinti sorrendét követve, 1. oldal. A kínai, kitan szavak elrendezése, valamint ezek olvasatai, leirásai és francia forditásai úgy tünnek, mintha Stein 1939: 9 és 110-147 helyröl lennének másolva.)

(7.) (64+ oldal a kitan szavak átírásának ábécé sorrendjében. A címszavakhoz a feltételezett rokon szavak történeti nyelvészeti és bibliográfiai adatai társulnak, gyakran kiegészitve egyéb kisebb lapbetoldásokkal, kézírásos jegyzettöredékekkel.)

zetei is magukon viselik. Az itt tárgyalt jegyzetei is túlnyomóan franciául készültek, szórványos magyar megjegyzésekkel, fordításokkal. Ami ebböl számunkra fontos, az az, hogy a kínai szavak francia átírásban szerepelnek.

9 Pontosabban a Shuofu 說郛 címü mű Liao zhi fejezete. Ld. Stein (1939) magyarázatát arról, hogy a Liao zhi szövege Tao Zongyi 陶宗儀 (kb. 1329-1410) ,primitív” (azaz kivonatos) Shuofu 說郛 szövegének az átvétele, amely utóbbi a Yuan korban kiadott Liao zhi-ből tartalmaz kivonatos részeket (ld. 1. ábra.). 
(II. mappa) Sur la langue de K'i-tan - Par Louis Ligeti [A kitanok nyelvéhez -Ligeti Lajos által] (Nagyjából A6 méretü indigó szinü kemény boritós füzött irattartó 168+ lappal és néhány további kiegészitö jegyzetlappal.)

(1.) Megfejtett kitaj szavak (Jegyzetekkel ellátott szójegyzék bibliográfiai stb. adatokkal, eredetileg valószinüleg a kitan szavak átírásának ábécé sorrendjében, de ez a sorrend a doboz felnyitásakor már nem volt betartva.)

(2.) Meg nem fejtett kitaj szavak (Jegyzetekkel ellátott szójegyzék bibliográfiai stb. adatokkal.)

(III. mappa) Notes sur le khitan. Mots khitan en transcription chinoise [Megjegyzések a kitan nyelvhez. Kitan szavak kínai átírásban] (Nagyjából A6 méretü indigószinü kemény boritós füzött irattartó 51 gépelt, ábécésorrendbe rendezett katalóguscédulával, amelyek közül mindegyik egy-egy kitan szót tartalmaz latin betüs átírásban, francia forditással.)

Ahogy látható Ligeti először 11 (az (I. 2.) első jegyzeteiben) majd 12 (az (I. 3.) letisztázott jegyzeteiben) kategóriába csoportosította a szavakat. Az eltérő felosztás annak tudható be, hogy a második jegyzetben felülvizsgálta a korábbi kategóriákat. A javított változat feltehetőleg a tárgyalás későbbi rendjének szolgált volna alapul, ahogy azt az (I. 3.) rész címadása is nyilvánvalóvá teszi, ennek ellenére egyik felosztást sem követte a szavak részletes leírásakor a (II.) mappában, ahol végül is ábécésorrendben következnek a szavak. 


\section{A számnevek}

(I. mappa) Szójegyzék ${ }^{10}$

\begin{tabular}{|c|c|c|c|c|}
\hline Szakasz & (I. 1.) & (I. 2.) I. & (I. 3.) I. & (I. 4.) \\
\hline \multirow[t]{4}{*}{$\begin{array}{l}\text { Ligeti } \\
\text { adatai }\end{array}$} & $\begin{array}{l}\text { 5. ja’’u "cent" } \\
\text { [száz] }\end{array}$ & $\begin{array}{l}\text { 1. nek'1' } \\
\llbracket n e, n e i \rrbracket\end{array}$ & 1. 'Un'-nek & $\begin{array}{l}\text { 1. nei 'un' } \\
\text { [egy] }\end{array}$ \\
\hline & $\begin{array}{l}\text { 16. qor "vingt" } \\
\text { [húsz] }\end{array}$ & $\begin{array}{l}\text { 2. taw '5' } \\
\llbracket \text { tau } \rrbracket\end{array}$ & 'Cinq' & $\begin{array}{l}\text { 2. taw 'cinq' } \\
\text { [öt] }\end{array}$ \\
\hline & $\begin{array}{l}\text { 21. nei "tête, } \\
\text { premier" [fej, elsö] }\end{array}$ & 3. jau ' 100 ' & 3. 'Cent'- jau & $\begin{array}{l}\text { 3. qori 'vingt' } \\
\text { [húsz] }\end{array}$ \\
\hline & 38. taw "cinq" [öt] & 4. qori ' 20 ' & 4. 'Vingt' - qori & $\begin{array}{l}\text { 4. ja'u'cent' } \\
\text { [száz] }\end{array}$ \\
\hline
\end{tabular}

(II. mappa)

ǰau „cent” [száz]

tchao

爪二百數也。LC CXVI, 21b

nei ,un"; ,tête" [egy; fej]

nai nei

妳 KTKT XXVII, 1a = 丁; 媮 (T'[oung] P[ao] XXXV, [p.] 110, [p.] 119, [p.] 120) LT=丁 【=頂 』 'pointe, début'; [csúcs, kezdet]

迺 LC LIII, 12b, CXVI, 15a = 正 【月》

nai

妳 KTKT XXVII, 26 = 頭; LT嬭 nai 'tête' [fej] (T'[oung] P[ao] XXXV, [p.] 134)

耐 LC LIII 13b = 首

" CXVI, 15b

10 Ligeti adatai a szerző által táblázatba rendezve. 
qor „vingt” [húsz]

houa li houen ho

書 $^{11}$ 里昏呵 KTKT (pen-mo[本末],1b) = LT 畫里昏呵 Houa li houen ho (T’ [oung] P[ao] XXXV, [pp.]12-13, [p.] 25) - Mind a három 主!

\section{taw ,cinq” [öt]}

t'ao

而 ${ }^{12}$ KTKT XXVII, 2a =-; LT 討 t'ao $=-\left(\mathrm{T}^{\prime}\right.$ [oung] P[ao] XXXV, [p.] 129, [p.] 131, cinquième) $)^{13}$ [ötödik] 討 LC LIII, 13a, CXVI, 15a=五

(III. mappa)

jau „cent” [száz]

(...)

qur „vingt” [húsz]

(...)

taw ,cinq” [öt]

(...)

nei „tête, un"〈x〉, ,premier” [fej, egy, elsö]

11 書 zhòu, megkülönböztetendő a 畫 huà írásjegytöl a Liao zhi-ben. Az eredetiség kérdésével kapcsolatban ld. a 20 számnévről szóló lentebbi megjegyzéseket.

12 Valószínüleg elírás a 討 írásjegy helyett, a KTKT 27-ben nincs 耐 írásjegy ebben a kontextusban, viszont van 討賽籬 'ötödik hónap' értelemben, tehát ugyanabban a jelentésben, amelyben Ligeti a következő Liao zhi példákat idézi Steintől. Első rátásra félrevezető az elírás, mert a 而 írásjegy fonetikai értéke könnyen illeszthető volna a kitan számnév nei/nai 'egy, első' kiejtéséhez. Ráadásul a Ligeti által írt - jel akár a kínai- 'egy' írásjegyként, akár pedig a címszó után írt egyszerü elválasztójelként is értelmezhető. Az elírás oka a Liao shi LIII 13b szakasza lehetett, amelyben a 而 írásjegy a kitan 'fontos; első; fej' jelentésü szó átírására áll az azonos jelentésủ kínai 首 írásjeggyel magyarázva. Ld. még Ligeti fenti jegyzeteit a nei 'egy; fej' szóról. Stein 1939. 


\section{A szerző megjegyzései}

Már a szójegyzék e kis szeletéből is látható, hogy nehéz megállapítani, egyegy kitan szónak mely rekonstrukciójára tekintett Ligeti olyanként, amely végső tudományos álláspontját leghívebben tükrözné. Az ultima manus elvét követve és feltételezve, hogy a gépelt szövegű cédulák jelentették munkájának a legkésőbbi, letisztázott állomását, az alábbi táblázatot rajzolhatjuk meg, amelyben az összes Ligetinél szereplő változat helyet kapott, félkövér szedéssel kiemelve a feltételezett végleges változatokat. ${ }^{14}$

\begin{tabular}{|c|c|c|c|c|}
\hline & \multicolumn{4}{|c|}{ Számnevek } \\
\hline & 1 & 5 & 20 & 100 \\
\hline \multirow{6}{*}{$\begin{array}{l}\text { A Ligeti } \\
\text { jegyzetei- } \\
\text { ben } \\
\text { szereplő } \\
\text { változatok }\end{array}$} & nei (I.1.) 21. & taw (I.1.) 38 . & gor (I.1.) 16. & ј̆а'u (I.1.) 5. \\
\hline & nek (I.2.) I. 1. & taw (I.2.) I. 2. & qori (I.2.) I. 4. & jau (I.2.) I. 3. \\
\hline & nek (I.3.) I. 1. & taw (I.3.) I. 2. & qori (I.3.) I. 4. & jau (I.3.) I. 3. \\
\hline & nei (I.4.) 1. & $\operatorname{taw}$ (I.4.) 2. & qori (I.4.) 3. & ј̆а'u (I.4.) 4. \\
\hline & nei (II.) & taw (II.) & qor (II.) & jau (2.) \\
\hline & nei (III.) & taw (III.) & $q u r$ (III.) & јаи (3.) \\
\hline
\end{tabular}

Figyelemre méltó, hogy Ligeti rekonstrukciói, amelyeket több mint 60 éve kizárólag a kínai forrásokban szereplő adatok alapján készített, alapvetően egybeesnek a legújabb tudományos eredmények következtetéseivel. Az 5-ös számnév (amely az egyik fő érve volt Janhunennek a kitan nyelv paramongol ${ }^{15}$ voltának a bizonyítására ${ }^{16}$ ) és a 100 viszonylag egyszerübb esetei tökéletesen

14 Ligeti három évtizeddel későbbi művében szereplő olvasatok is ezeket a formákat támasztják alá: taw, jau (Ligeti 1986: 428).

15 A kitan nyelv mongollal való rokonsága már Ligeti idejében is ismert volt, a rokonság foka körülötti bizonytalanság azonban csak az elmúlt egy-két évtized kutatásai nyomán látszik tisztulni. A jelenleg többé-kevésbé általánosan elfogadott nézet szerint a kitan nem közvetlenül a mai mongol nyelvek őséből, a feltételezett protomongol ágból, hanem egy azzal nagyjából párhuzamosan létezett úgynevezett paramongol ágból alakult ki más, szintén kihalt nyelvekkel (például tabgacs tagbacs; shiwei $\sim$ serbi). E nyelvek rokonsági besorolását sokáig nehezítette, hogy az államalakulatok, amelyekhez beszélőik tartoztak, jellemzően soketnikumúak és nyelvileg is heterogének voltak, és a kevés rendelkezésre álló forrás miatt ezek egymáshoz való viszonya a mai napig sem megnyugtatóan tisztázott. A protomongol és paramongol további jellemzőiről ld. Janhunen 2003: 1-29, illetve 391-402. 
egyeznek a jelenlegi tudományos olvasatokkal. ${ }^{17}$ A valóban jelentős különbségek csupán a 20 kínai adatának értelmezésében, valamint a nei tényleges vagy legalábbis kváziszámnévként történő kezelésében mutatkozik, ezért ezeknek az esetében egy rövid összefoglalást adok a hozzájuk kapcsolódó jelenlegi tudományos álláspontokról. ${ }^{18}$

\section{Az 'egy' számnév}

A szemantikai bizonytalanság tisztán tetten érhető Ligeti jegyzeteiben, ld. a fordításait 'fej, első' az (I. 1. részben) és 'egy' a (I. 4. részben). Ligeti igyekezete, amellyel ezt a szót egy hozzá nehezen kapcsolható, de szemantikailag odailleszthető mongol szóval próbálta összekötni, szintén könnyen észrevehetö a kísérletező nek olvasatból az (I. 2.) I. 1. és (I.3.) I. 1 részekben, viszont az, hogy később a gépelt oldalakon már feladta ezt a változatot, bizonyítja elfogulatlan tudósi hozzáállását. Jelenlegi tudásunk szerint ennek a kitan szónak nincs 'egy' jelentése, viszont más kifejezésekben fennmaradt ide kapcsolható jelentésben.

Róna-Tas ezek közé sorolja a nai (kis kitan írás: 穴) és mas (モ and モ) $)^{19}$ szavakat, és a nai szerepét az ótörök baš-éhoz 'fej, vezetö, első' hasonlítja. ${ }^{20}$ A ,rendes” egy tőszámnevet mas formában rekonstruálja. ${ }^{21} \mathrm{Ez}$ a feltételezés szembemegy korábbi megállapításokkal. ${ }^{22}$

Shimunek hozzáteszi, hogy az alacsonyabb kitan tőszámnevek rekonstrukciójakor azt a megfigyelést is figyelembe kell venni, miszerint minél alacsonyabb a szám, annál nagyobb a rendellenes kialakulásának a valószínü-

17 Habár Chinggeltei, Wu és Jiruhe (2017: 165) egy hipotetikus, a mongol nyelvekből ismert $-n$ tövü $<$ ' 'au-n ${ }^{\circ}>$ olvasatot rendel a ponttal ellátott alakhoz.

18 A 厉 *jau 'száz'-zal kapcsolatban (Liao shi/Guo yu jie: 爪百數也 zhao bai shu ye 'a zhao százat jelent') ld. Chinggeltei 1985: 158; Kara 1997 225, 2005: 17; RónaTas 2016b: 134. Az 'öt' jelentésü 毛/戔 tau-hoz ld. Liao shi/Guo yu jie: 五曰討 wu yue tao 'az ötöt tao-nak mondják', ld. még Kara 1997: 225-226; Róna-Tas 2016b: 128.

19 Az a tény, hogy a 穴 az első tíz szám tőszámneveitől eltérően nem rendelkezik grammatikai nemjelölésü párral, valamint az, hogy sok más nyelvben sincs összefüggés az 'egy' és az 'első' jelentésü szavak között, arra engednek következtetni, hogy ez sem függ össze az 'egy' tőszámnévvel, vö. Shimunek 2017: 228; Kane 2009: 38. Róna-Tas 2016b: 126.

21 Vö. Róna-Tas 2016b: 126; Shimunek 2017: 233.

22 Janhunen 2003: 400. 
sége. ${ }^{23}$ Ő az olvasatában *mas(?) helyesen jelzi, hogy az hipotetikus, és mindössze a 不冬余/ $<<^{*}$ m.as.qu/qú-> 'első ${ }^{24}$ előforduláson alapszik. ${ }^{25}$ Viszont az, hogy kizárja a $<*$ m.as.qu/qú-> alakot a sorszámnevek közül azon az alapon, hogy a *mas(?) önmagában spekulatív, részletesebb magyarázatot igényelt volna. Róna-Tas ötlete, hogy a mongol emüne vagy valószínűbben emünesi 'elöl, előbb' szavakat figyelembe lehet venni rokon szavakként. ${ }^{26}$ Kane azon megfigyelésére megy vissza, miszerint a szónak két különböző lejegyzése ismert a Dao+gai (i. sz. 1101) feliraton: egyszer mint a 代企全え $<$ mu.em.se.gi $>$, egyszer pedig a $千$ 千 $え<$ ONE.se.gi $>$ első tagjaként, amelyek nyomán a モ olvasata $<$ mu.em> *mem. ${ }^{27}$ Kane ezt a ' [család] legidösebb [tagja]' jelentéshez kapcsolta, lehetséges kapcsolódással a 叉及 <m.o > 'nagy' kifejezéshez. ${ }^{28}$ Ennek ellentmond Chinggeltei, Wu és Jiruhe (a továbbiakban: CWJ) 2017-es nézete, amely szerint a 天不冬余示儿厽 (Zhen 8 szöveg $^{29}$ ) a Jin-dinasztia korában írott sor nem valószínü, hogy 'Nagy Kitan Állam', hanem inkább 'Első Kitan Állam' értelmében állhatott, mivel a későbbi dinasztiákra nem volt jellemző, hogy az általuk leváltott korábbiakat magasztos jelzőkkel lássák el. ${ }^{30}$ Vovin szintén kifejezte kétségeit Kane ötletével kapcsolatban, hogy a szót a <m.o> 'nagy' kifejezéshez kössük, viszont kínált egy lehetséges közép-koreai mìt mìs 'legidősebb' rokonítást a kitan *mas

23 Shimunek 2017: 231.

24 Shimunek 2017: 233. Frissebb cikkében, amelyben hipotetikus shiwei *Vmš (*amš ?) 'egy' olvasattal igyekszik kapcsolatba hozni a szót, már eltávolította a kérdőjelet a *mas olvasat mellöl (Shimunek 2018: 338).

Kane 2009: 38, 48, 50; a kitan írásos Xiang felirat: 10-26 20. A kitan feliratokra vonatkozó rövidítések a Belső-Mongol Egyetem és az MTA kutatói által közösen megállapított listát követik, részleteket ld. Sigla of the Major Inscriptions in Khitan Small Script (Apatóczky-Róna-Tas 2019: 266-268). Kane oldalszám nélkül idézi Chinggeltei 1986 (?)-os müvét a $<*$ m.as.qu> 'első' kapcsán, viszont ilyen mü sajnos nem szerepel a bibliográfiájában. Róna-Tas 2016b: 126.

27 Kane 2009: 110. Shimunek nem fogadja el ezt az érvelést a hozzáférhető pacskolatok gyenge minőségére hivatkozva (Shimunek 2018: 337, 16 lj., és noha az ötletet Ji Shinek tulajdonítja [= Batu] 2012, a kérdést Kane szerint (2009: 38) Chinggeltei vetette föl 1986 (?)-os mủvében, a CWJ 163 pedig szintén Chinggeltei (2002)-es müvében. A CWJ-ben hozzáférhető pacskolatok (614 és 618) alátámasztják Shimunek kétkedését, mivel ugyan az emendált változat tisztán olvasható, az első felbukkanás írásjegyei alig láthatók még a jó minőségü nyomtatványban is.

29 Vö. Apatóczky-Róna-Tas 2019: 267.

30 CWJ 164. 
szóhoz, hangsúlyozva, hogy a kitan szó nem általánosan jelentett 'első'-t, mivel kizárólag rokoni viszonyok meghatározására használták. ${ }^{31} \mathrm{Az}$ ő javaslatát figyelembe véve egy további helyesbítést is tehetünk azzal, hogy a 天 尽 又冬余不儿交 szakaszt 'Rég(ebb)i/korábbi Kitan Állam'-ként állítjuk helyre.

Anélkül hogy az eredet kérdésének végső eldöntésére tennénk kísérletet, javaslatom szerint ennek a számnévnek a vizsgálatát hasznosabb a tunguz nyelvek számneveiben (mind tő-, mind sorszámnevek) megőrződött lehetséges kitan (vagy inkább paramongol, vö. Shimunek Shiwei-rekonstrukcióit ${ }^{32}$ ) fosszíliáknak a kérdéskörébe utalni. Ilyenek például a mandzsu ети 'egy', етисi 'első' (juweci 'második' és duici 'negyedik' stb.), amelyekkel közelebb kerülhetünk a モ/モ helyes olvasataihoz. ${ }^{33} \mathrm{~A}$ CWJ-ben részletes filológiai elemzését találjuk ezeknek az írásjegyeknek, amelynek következtetése szerint a tunguz adatokkal való összevetés helyénvaló, és amelynek ott szereplő eredményeként a $€ / モ$ kérdéses olvasatai $*<$ əmu $>/ *<$ วmus $^{0}>{ }^{34}$ utóbbiban az $-s$ az írásjegy grammatikai nemet jelölő pontjának felel meg. Noha meggyőző érveléssel támasztják alá olvasatukat, magyarázatuk nem zárja ki a mássalhangzó szótagkezdő lehetőségét, ezért további adatok előkerüléséig a モ/モ karakterek olvasataként az $<*$ əmu $>/<$ əmus $^{\circ}>($ ?) alakot kérdőjellel látnám el, és kiegészíteném a $<^{*}$ mə $>/<$ məs $^{\circ}>\left(\right.$ ?) olvasattal. ${ }^{35} \mathrm{~A}$ 穴 nai 'fej, első' írásjeggyel (Ligetinél: nei) kapcsolatos tudományos álláspont jelenlegi tudásunk szerint is változatlanul fenntartható.

\section{A ’húsz’ számnév}

A korábbi szakirodalom a Liao zhi-ben szereplö 畫里昏呵 szakasz 畫 huà írásjegyét hiteles és eredeti alaknak tekintette, míg a Qidan guo zhi-beli 書里 昏呵 szakasz 書 zhòu írásjegyét szövegromlás eredményének tartotta, és

\footnotetext{
Vovin 2017: 208.

Shimunek 2018: 337-341.
}

33 Bár Hölzl Róna-Tas kitan olvasatait használva készített táblázatot egy hipotetikus paramongol nyelv számneveiről, nem említette meg Róna-Tas saját kétségeit a *mas olvasatról (Hölzl 2017: 107), és szintén megfeledkezett a számnevek tunguzhoz kapcsolható alternatív olvasatainak a megemlítéséröl. A szó lehetséges tunguz kapcsolatainak ötletét már Ji Shi felvetette (1986: 89-90). CWJ 163-165.

35 Shimunek hipotetikus Shiwei-rekonstrukciói *Vmš (*amš ?) 'egy’ többszörös, egymásra épülő feltételezéseken alapulnak, ezért nem állítom velük párhuzamba (Shimunek 2018: 341). 
ennek megfelelően kitan *xor(i)/*xur(i) 'húsz'; xurixan 'nagyjából húsz; alig húsz' és ehhez hasonló alakokat rekonstruált. ${ }^{36}$ A feltételezéssel egyezően a kis kitan 丁 írásjegyet sokáig kuri/huri stb. alakban rekonstruálták. A legújabb kitan kutatások irodalmát olvasva világosnak tünik, hogy az ilyen, közmegegyezésen alapuló rekonstrukciók tekintetében is mindig van helye kritikának. Chinggeltei már 1997-ben írt annak a szükségességéről, hogy a 畫 / 書 alakváltozatok addig előbbitől az utóbbi felé mutatónak tartott szövegromlását újra kell vizsgálni. ${ }^{37}$ Vélekedése szerint elképzelhető, hogy a 書 írásjegy az eredeti a szövegben, ez pedig alapjaiban változtatja meg az olvasatot. Közel két évtizeddel később, 2016-ban szintén Chinggeltei és tanítványai az alábbiak szerint összegezték ezt a nézetet: a 書 zhòu írásjegy egy kitan /*tcyr/ 'húsz' alakot tükrözhet, amely a /*turu/ 'második' sorszámnévvel és végső fokon a *jür 'kettő' (机化〈či.ur>) számnévvel állhat kapcsolatban. ${ }^{38}$ Ennek a nézetnek hiányossága, hogy az általuk/tgiəulihuən/ alakban kiolvasott 書里昏 szakasz - $i$ - hangját figyelmen kívül hagyja, noha ez fontos elemnek tünik. Róna-Tas András még ugyanabban az évben tovább finomította a feltételezést. ${ }^{39} \mathrm{Az}$ ő véleménye szerint a *jüri(n) 'húsz' alak megy vissza a *jür 'kettő' szóra (hasonlóan a mongolból ismert tabi(n) 'ötven' esetére). Amennyiben valóban a 書 $z h o ̀ u$ írásjegy volt az eredeti átírásban, úgy Róna-Tas érvelése meggyőzőbb. ${ }^{40}$ Egy másik, közvetett bizonyíték, hogy míg a mongol nyelvek kettes számneve a qoyar, a kitanban ez *jür /*tur/, tehát ha a kitanban *qor(in)/*qur(in) alakot feltételeznénk a 'húsz' jelentésében a 'kettő' számnévböl származtatva, akkor a feltételezés magában foglalná azt is, hogy a qoyar

\footnotetext{
Ji 1986: 96.

Chinggeltei 1997.

CWJ 151.

Róna-Tas 2016b: 133.

40 Shimunek alapvetően egyetért ezzel a nézettel, viszont az ő olvasata *juri, amelyet a „közép-kitan magánhangzóváltás” elnevezésű hipotézisének egy elemére, azaz az ajakkerekítéses magánhangzók összeolvadására alapít. E szerint, a közös serbi-mongol */u/, */o/, */ひ/ a közép-kitanban */u/ és */o/ lett, míg a */wə/ a közép-kitanban */o/-vá változott. Ez párhuzamba állítható Seongyeon Ko ötletével $(2011,2013)$, amely szerint a régi mongolban nem első/hátsó nyelvállás szerinti magánhangzó-harmónia, hanem elöretolt/hátrahúzott nyelvgyök szerinti harmónia érvényesült (Shimunek 2017: 214-215 és 238, valamint xiv).
} 
egy rokon alakjának kellett volna a kitanban (továbbá a protomongol és paramongol közös protonyelvében ${ }^{41}$ ) is a 'kettő' jelentésü eredeti szónak lennie (és ennek megfelelően a qoyar régebbi volna a ǰirin alaknál és rokonainál). Mindez azonban igen valószínütlen és szélsőségesen hipotetikus.

\section{Konklúzió}

Annak ellenére, hogy a kitan - szélesebb értelemben pedig a paramongol számnevek kérdése a kitan nyelvi kutatások homlokterében volt az elmúlt hetven évben, még mindig messze vagyunk e számnevek minden tekintetben kielégítő leírásától, nem beszélve az ezek által kimutatható paramongol (és emellett esetleges régi tunguz) nyelvi kapcsolatokéról. A történeti nyelvészettel foglalkozók hosszú utat tettek meg, mire jelenlegi tudásunk szintjére emelték a témát, és közöttük Ligeti Lajos, a XX. század eminens tudósa volt az úttörők egyike, aki megalapozta ezen ismereteinket. Ebben a rövid értekezésben összefoglaltam a tudósi jegyzeteiből már az 1950-es évek elejétől kiolvasható, de nem publikált nézeteit a kitan számjegyekről, valamint ismertettem azokat a friss álláspontokat ezekkel kapcsolatban, amelyekben a modern kutatások eredményei eltérnek Ligetiéitől. Mindezek mellett kisebb korrekciókat javasol-

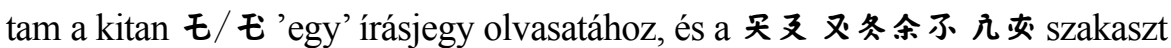
'Rég(ebb)i/korábbi Kitan Állam'-ként fordítottam.

\section{Elsődleges források}

Liaoshi遼史 facsimile: https://ctext.org/library.pl?if=en\&file=80017.

MTAK Kézirattár Ligeti Lajos hagyaték 1/2(4); 5/4(4); 5/3(4).

Qidan guo zhi 契丹國志 facsimile: https://ctext.org/library.pl?if=en\&file= 104543 .

Shuofu/Liao zhi fejezet 說郛遼志 facsimile: https://ctext.org/library.pl?if=en\&file=81665.

\section{Felhasznált másodlagos szakirodalom}

Apatóczky, Ákos Bertalan - Róna-Tas, András 2019. „A new comprehensive monograph on Khitan" (review article). Acta Orientalia Academiae Scientiarum Hungaricae 72/2: 259-268. https://doi.org/10.1556/062.2019.72.2.7

41 Azaz Janhunent követve a preprotomongolban (Janhunen 2003: 391). 
Chinggeltei (Qingge'ertai 清格尔泰) et al. 1985. Qidan xiaozi yanjiu 契丹小字研究 [Research on the Khitan Small Script]. Beijing: Zhongguo shehui kexue chubanshe. Chinggeltei (Qingge'ertai 清格尔泰) 2002. Qidan xiaozi shidu wenti 契丹小字釋讀 問題 [Problems of the interpretation of the Kitan small script]. Tokyo: Research Institute for Languages and Cultures of Asia and Africa, Tokyo University of Foreign Studies.

Chinggeltei (Qingge’ertai 清格尔泰) 1997. „Qidanyu shuci ji qidan xiaozipin dufa” 契丹 语数词及契丹小字拼读法 [The Khitan numerals and the reading of the Khitan Small Script graphic combinations]." Nei Menggu daxue xuebao (Zhexue shehui kexueban) 内蒙古大学学报 (哲学社会科学版) 4: 1-9.

CWJ = Chinggeltei $-\mathrm{Wu}$ Yingzhe - Jiruhe 2017. Qidan xiaozi zai yanjiu 契丹小字再 研究 [Further Research on Khitan Small Script]. Vols. I-III. Beijing.

Hölzl, Andreas 2017. „New evidence on Para-Mongolic numerals”. SuomalaisUgrilaisen Seuran Aikakauskirja/Journal de la Société Finno-Ougrienne 96: 97113. https://doi.org/10.33340/susa. 70222

Ishida, Mikinosuke 1934. „De vocabulario sinico-mongolico. Chih-yuan i-yu. 至元譯語 composita (sic!) circa Saeculum XIII.” Tōyōgaku sōhen (Philologia Orientalis) 1: 1-26.

Janhunen, Juha (ed.) 2003. The Mongolic languages. London: Routledge.

Ji Shi 即实 [= Batu] 1986. „Guanyu Qidan shuci yindu wenti 䏌于契丹数词音读问题 [On the reading problems of the Khitan numerals]." Neimenggu daxue xuebao 1986/4: 89-100.

Ji Shi 即实 [= Batu] 2012. Mitian gengyun: Qidan xiaozi jiedu xu 谜田耕耘 : 契丹小字解读续 [Thorough processing of a riddle - continuing the decipherment of Khitan Small Script]. Shenyang.

Kane, Daniel 2009. The Kitan Language and Script. Brill: Leiden-Boston. https://doi.org/10.1163/ej.9789004168299.i-306

Kara, György [= Qaradorji] 1997. „Kitan kelen-ü toyan-u neres [Numerals in Khitan].” In: Lunwen yu jinianwen, jininan Qingge'ertai jiaoshou congjiao 50 zhou nian wenji. Neimenggu daxue, 225-227.

Kara, György 2005. Books of the Mongolian Nomads: More Than Eight Centuries of Writing Mongolian. Bloomington: Indiana University, Research Institute for Inner Asian Studies.

Ko, Seongyeon 2013. „The end of the Korean Vowel Shift controversy”. Korean Linguistics 15.2: 199-221. https://doi.org/10.1075/kl.15.2.02ko

Ko, Seongyeon 2011. „Vowel contrast and vowel harmony shift in the Mongolic languages". Language Research 47/1: 23-43.

Ligeti Lajos 1927. „A kitaj nép és nyelv.” Magyar Nyelv 23: 293-310.

Ligeti Lajos 1986. A magyar nyelv török kapcsolatai a honfoglalás elött és az Árpádkorban. Budapest: Akadémiai Kiadó.

Róna-Tas, András 2016a. „Remarks on the ethnonym Khitan.” Turkic languages 20: 157-169. 
Róna-Tas, András 2016b. „Khitan studies I. The graphs of the Khitan small script. 1. General remarks, dotted graphs, numerals." Acta Orientalia Academiae Scientiarum Hungaricae 69/2: 117-138. https://doi.org/10.1556/062.2016.69.2.1

Róna-Tas, András 2019. „Egy ismeretlen írás és nyelv megfejtése: a kitan.” Magyar Tudomány 2019/12: 1846-1856. https://doi.org/10.1556/2065.180.2019.12.10

Shimunek, Andrew 2018. „Early Serbi-Mongolic - Tungusic lexical contact: Jurchen numerals from the 室韋 Shirwi (Shih-wei) in North China.” In: Ákos Bertalan Apatóczky - Christopher P. Atwood (eds.): Philology of the Grasslands. Essays in Mongolic, Turkic, and Tungusic Studies. Brill, Languages of Asia 17, 331-346. https://doi.org/10.1163/9789004351981_019

Shimunek, Andrew 2017. Languages of Ancient Southern Mongolia and North China. Wiesbaden: Harrassowitz. https://doi.org/10.2307/j.ctvckq4f7

Stein, Rolf 1939. „Leao-tche (遼志)”. T'oung Pao, Second Series, Vol. 35, 1/3: 1-154. https://doi.org/10.1163/156853239X00017

Vovin, Alexander 2017. „Koreanic Loanwords in Khitan and Their Importance in the Decipherment of the Latter." Acta Orientalia Academiae Scientiarum Hungaricae 70/2 (Special issue on the Khitan Studies ed. by Ákos Bertalan Apatóczky): 207-215. https://doi.org/10.1556/062.2017.70.2.4

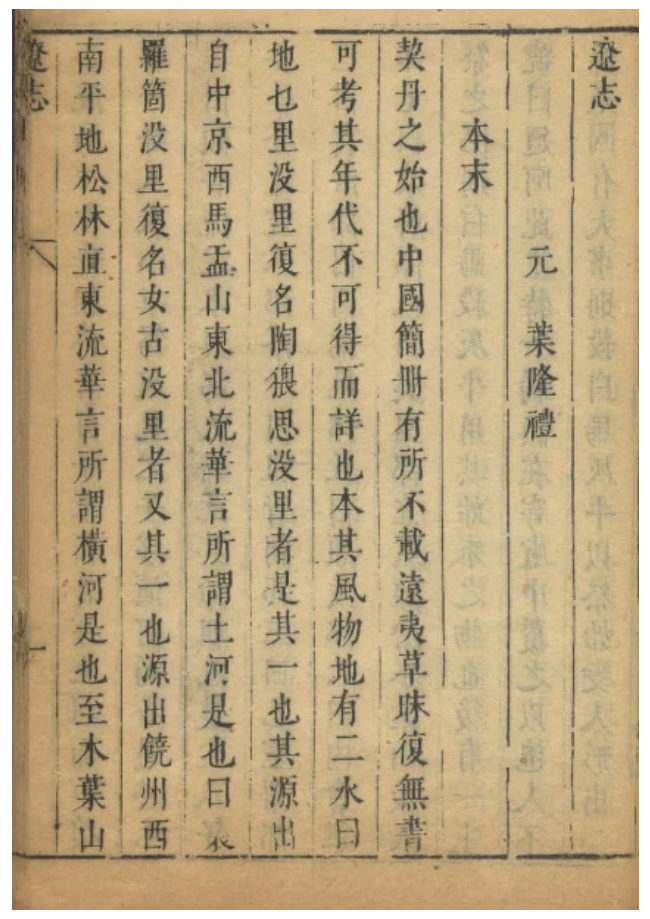

1. ábra. A Shuofu címü mü Liao zhi fejezetének első oldala (Forrás: https://ctext.org) 